\title{
Glass ionomer cement as alternative treatment for vulnerable geriatric patients with caries or cavities
}

\begin{abstract}
This work is a literature review on the use of Glass Ionomer Cement (GIC) for Atraumatic Restorative Treatment (ART) of elderly patients. The research was conducted online, using available academic database platforms, such as a PubMed. It was concluded that the ART is an adequate treatment approach for caries in elderly patients. It presents similar efficiency to the conventional treatment and advantages, such as biocompatibility, anticariogenic action, simplicity, no anesthesia or rotary equipment. Furthermore, it is both cost and time effective while more teeth can be treated per session. However, clinical evidence on the technique being applied to elderly patients is still relatively scarce.
\end{abstract}

Keywords: aging, odontogeriatrics, glass ionomer cement, root caries

\author{
Volume 4 Issue 4 - 2019
}

\author{
Miriam Fernanda Vieira Gazzotto,' Denise \\ Tibério, ${ }^{2}$ Marcelo de Faria Souza Ávila, 'Tânia \\ e Silva Pulicano Lacerda' \\ 'Dental prosthesis, São Leopoldo Mandic, Brazil \\ ${ }^{2}$ Faculty of Medicine and Dentistry, São Leopoldo Mandic, Brazil
}

Correspondence: Tânia e SP Lacerda,Associate Professor of Dentistry, Universidade Cidade de São Paulo and São Leopoldo Mandic Graduate Center, Brazil,Tel 55I 1967570600,

Email tanialacerda@col.odo.br

Received: May 21, 2019 | Published: July 10, 2019

\section{Introduction}

This work aims at a bibliographical review on the efficacy of Glass Ionomer Cement (GIC) and its feasibility in a traumatic restorative treatments (ART) for geriatric patients. The research was conducted online, primarily at PubMed - the academic database platform. Due to its focus on a specific age group, the terms of research were divided in three parts: i) "Elderly AND atraumatic restorative treatment AND root caries"; ii) "Elderly AND atraumatic restorative treatment AND glass ionomer cement"; and iii) Glass ionomer cement AND root caries". Out of all the works found, 21 tackled the issue specifically. The existing literature, thus, has indicated that glass ionomer cements are ideal because of their advantages in terms time, costs, and clinical application. Nevertheless, more randomized and controlled studies are needed to offer more conclusive answers on its efficacy in the treatment of cavity lesions in elderly patients, as well as the advantages of using such technique.

The last decades have witnessed a substantial growth of the aging population in the world. Estimates show that the number of people over 65 will reach 1,5 billion by 2050 . Thus, the projected population trends require more attention to health care, including oral health for the elderly. ${ }^{1}$ Nowadays, due to the betterment in oral health care and increase in life expectancy, many elderly citizens have been aging without losing their natural teeth. ${ }^{2-5}$ Among this age group, the reduction of salivary flow, development of systemic diseases, changes in local conditions, and many other unfavorable factors may lead to a number of different oral conditions, among which cavities and periodontal diseases are the most common. ${ }^{6}$

A dental cavity continue to be a major public health issue across the globe and has been confirmed as the most prevalent chronic condition among 291 investigated diseases between 1990 and 2010 (global prevalence of $35 \%$ for all ages). ${ }^{7}$ Studies estimate that $60 \%$ of individuals over 60 present root caries or uncovered dental restorations. ${ }^{8}$ Root caries represent a progressive, multi factorial chronic lesion, with irregular, darkened and softened tissue involving the root surface and can affect the cement, dentin, and enamel; it is very common among elderly patients, especially those with cognitive or physical disabilities. ${ }^{9-12}$ Burrow \& Stacey ${ }^{9}$ highlight that the high root carie rates in elders has been growing and the philosophy centered on a conservative treatment will likely provide these patients more chances to keep their teeth. ${ }^{9}$ Besides, oral bacterias can be introduced in the circulatory system through infected teeth or caries, forming vegetations in compromised cardiac valves. The Staphylococcus aureus and the Streptococcus viridans can be present in the oral cavity and are the organism most commonly responsible for infectious endocarditis. Dental infections have been implicated in more than a third of infectious endocarditis cases. Therefore, it is of the utmost importance to treat caries and periodontitis as soon as possible in order to avoid deterioration once heart diseases can be fatal or affect other organs. ${ }^{13,14}$

However, depending on how these people age and live, the dentist's plan of action can change. In the aging process, patients not rarely lose physical abilities, such as vision, motor skills, and mobility, which can all present challenges to their autonomy and maintenance of their own oral health. At other times, there may also be cognitive loss stemming from some kind of dementia. In all of the aforementioned situations, these elders will need caregiver's attention. Sometimes, however, instead of a trained professional, a family member or a somewhat informally hired person without proper know-how performs this role.

The social component is relevant to the establishment of a treatment plan. A lot of patients demand home care because of their vulnerability or inability to go to the office. Either at home, a retirement community, or an institution, the treatment needs to take into consideration efficacy, time, costs, and maintenance of the patient's health, focusing on their life as a whole. Bearing in mind that this patient might be terminal or in advanced age, professionals should avoid oral rehabilitation plans with prostheses, implants, or any complex restorative treatments. Nowadays, the concerns regarding institutionalized patients have been rising, given the numerous barriers for the dental treatment. Therefore, there is a recurrent need for more conservative, cost and time effective materials that can be utilized outside the dentist's office. Thus, a traumatic restorative treatment (ART) has been discussed and recommended since the 1980s. It consists of the removal of carious tissue (infected dentin) with manual instruments under relative isolation and use of glass 
ionomer cements. ${ }^{15,16}$ At first, ART became a highly accepted line of treatment for pediatric patients, once there is no need of anesthesia and rotative instruments. ${ }^{17,20}$ Throughout time, ART has also proved to be successful in systemic reviews that do not show differences in longevity in relation to conventional treatments that utilize resins or amalgam. Because of that, ART has been suggested as an alternative strategy of cavity control in elderly patients, once it is simple and more cost-effective in comparison to conventional techniques. ${ }^{21,23}$ Even though the use of ART and its success rates in permanent teeth have been documented in the literature, ${ }^{24,21}$ many dentists are still reluctant to its adoption in their daily practice, especially when it comes to adults and elders. ${ }^{9}$ The method is promising as a way of dealing with cavity lesions of root caries and can be a useful alternative for institutionalized patients who are incapable of paying a visit to the dentist's office on a regular basis, proving to be a better kind of treatment in elderly after one year in comparison to conventional restorations. ${ }^{12,23-25}$ Another advantage of ART is the possibility of conducting multiple restorations in different quadrants, once local anesthesia is not needed. Mata et al. ${ }^{26}$ compared ART's durability to a conventional restorative technique in elders after 5 years. The results show an $85 \%$ survival rate for ARTs, demonstrating its place as an efficient tool to provide dental treatment for vulnerable elders, particularly in non-clinical environments. Gonzalez \& Zuluaga ${ }^{9}$ Balgi et al. ${ }^{27}$ Serpa et al. ${ }^{28}$ Dornellas et al. ${ }^{29}$ Amer \& Kolker, ${ }^{4}$ Amorim et al. ${ }^{21}$ also concluded that ART restorations were considered clinically well succeeded with excellent results.

Glass Ionomer Cement (GIC), which was developed in 1969 by Wilson and Kent ${ }^{3-5,30}$ is the material used for this technique and has shown good results. Ever since, many researchers have studied and modified its composition to improve the mechanical properties involving adhesion to the dental substrate and anti-carious properties due to the liberation of fluorine ions. ${ }^{17,25,31-34}$ Besides, GIC presents thermal expansion coefficient similar to the tooth's structure, biocompatibility, low cytotoxicity, ${ }^{32,35}$ favorable work time, low cost, minimum contraction of polymerization, good marginal sealing properties, easy application, antimicrobial activity ${ }^{34}$ and easy manipulation. ${ }^{25}$ Davidson $^{33}$ had already mentioned that GIC could become the most reliable restorative material in less invasive dentistry. According to him, GIC can be called active as it liberates fluorine and can also be called an intelligent material once it releases fluorine according to acidity, acting somewhat as a $\mathrm{pH}$ controller.

The GIC of high viscosity presented better performance than the low or medium viscosity ones in $\mathrm{ART},{ }^{25}$ and in some works, the GICs modified by resin presented compatible mechanical properties to composite resins, being as efficient as the conventional technique..$^{22,24,36}$ The encapsulated GICs present superior numbers when it comes to resistance to compression compared to the powder/liquid system because the proportions are pre-balanced in the factory. ${ }^{37,38}$ According to Cajazeira et al. ${ }^{19}$ another advantage of GICs is that their longevity is not influenced by the use of a dental dam, making its use even easier, both in children and elders. However, some factors may contribute to the failure of the ARTs with glass ionomers cement, such as quality of the material and operator. ${ }^{20,33-35}$

\section{Conclusion}

Based on the available literature online, ART is an adequate treatment approach for caries in elderly patients. It presents similar efficiency to the conventional treatment and advantages, such as biocompatibility, anti cariogenic action, simplicity, no anesthesia or rotary equipment. Furthermore, it is both cost and time effective while more teeth can be treated per session. However, clinical evidence on the technique being applied to elderly patients is still relatively scarce.

\section{Acknowledgments}

None.

\section{Conflicts of interests}

The authors of this manuscript have no competing interests.

\section{References}

1. Jiang Q, Liu J, Chen L, et al. The oral microbiome in the elderly with dental caries and health. Front Cell Infect Microbiol. (2019);8:442.

2. Belibasakis GN. Microbiological changes of the ageing oral cavity. Archives of Oral Biology. 2018;96:230-232.

3. Silva M, Hopcraft M, Morgan M. Dental caries in Victorian nursing homes. Aust Dent J. 2014;59(3):321-328.

4. Amer RS, Kolker JL. Restoration of root surface caries in vulnerable elderly patients: a review of the literature. Spec Care Dentist. 2013;33(3):141-149.

5. Hayes M, da Mata C, Cole M, et al. Risk indicators associated with root caries in independently living older adults. Journal of Dentistry. 2016;51:8-14.

6. Lacoste FMH, Hermabessière $\mathrm{S}$, Jézéquel F, et al. L'écosystème buccal chez le patient âgé. Gériatrie et Psychologie Neuropsychiatrie du Vieillissement. John Libbey Eurotext. 2013;11:144-150.

7. Marcenes W, Kassebaum NJ, Bernabé E, et al. Global burden of oral conditions in 1990-2010: A systematic analysis. J Dent Res. 2013;92(7):592-597.

8. Eke PI, Wei L, Borgnakke WS, Thornton-evans G, Zhang X, Lu H et al. Genco. Periodontitis prevalence in adults $\geq 65$ years of age, in the USA. Periodontology 2000. 2016;72:76-95.

9. Gonzalez ACC, Zuluaga DJM. Clinical outcome of root caries restorations using ART and rotary techniques in institutionalized elders. Braz Oral Res. 2016;30(1):e638

10. Matthews DC1, Clovis JB, Brillant MG, et al. Oral health status of longterm care residents-A vulnerable population. J Can Dent Assoc. 2012;78:c3.

11. Philip P, Rogers C, Kruger E, et al. Caries experience of institutionalized elderly and its association with dementia and functional status. Int J Dent Hygiene. 2012;10:122-127.

12. Burrow MF, Stacey MA. Management of cavitated root caries lesions: minimum intervention and alternatives. Monogr Oral Sci. 2017;26:106114.

13. Baldin M, Srinivasan B, Sharma S. Dental infection as a cause of bacteraemia in infective endocarditis. Dent Update. 2018;45: 357-358.

14. Thornhill MH. Infective endocarditis: the impact of the NICE guidelines for antibiotic prophylaxis. Dent Update. 2012;39(1):6-10.

15. Calvo AF, Kicuti A, Tedesco TK, et al. Evaluation of the relationship between the cost and properties of glass ionomer cements indicated for atraumatic restorative treatment. Braz Oral Res. 2016;30.

16. Ersin NK, Candan U, Aykut A, et al. A clinical evaluation of resin-based composite and glass ionomer cement restorations placed in primary teeth using the ART approach: results at 24 months. J Am Dent Assoc. 2006;137(11):1529-1536. 
17. Alves FB1, Hesse D, Lenzi TL, et al. The bonding of glass ionomer cements to caries-affected primary tooth dentin. Pediatr Dent. 2013;35(4):320-234

18. Bonifácio CC, Hesse D, Raggio DP, et al. The effect of GIC-brand on the survival rate of proximal-ART restorations. Int $J$ Paediatr Dent 2013;23(4):251-258.

19. Cajazeira MR, De Sabóia TM, Maia LC. Influence of the operatory field isolation technique on tooth-colored direct dental restorations. Am J Dent. 2014;27(3):155-159.

20. Olegário IC, Pacheco AL, de Araújo MP, et al. Low-cost GICs reduce survival rate in occlusal ART restorations in primary molars after one year: A RCT. J Dent. 2017;57:45-50.

21. de Amorim RG, Leal SC, Frencken JE. Survival of atraumatic restorative treatment (ART) sealants and restorations: a meta-analysis. Clin Oral Invest. 2012;16:429-441.

22. Raggio DP, Hesse D, Lenzi TL, et al. Is Atraumatic restorative treatmen an option for restoring occlusoproximal caries lesions in primary teeth? A systematic review and meta-analysis. Int J Paediatr Dent. 2013;23(6):435443.

23. da Mata C, Allen PF, Cronin M, et al. Cost-effectiveness of ART restorations in elderly adults: a randomized clinical trial. Community Dent Oral Epidemiol. 2014;42:79-87.

24. da Mata C, Allen PF, McKenna G, et al. Two-year survival of ART restorations placed in elderly patients: A randomised controlled clinical trial. Journal of Dentistry. 2015;43(4):405-411.

25. Saber AM, El-Housseiny AA, Alamoudi NM. A traumatic restorative treatment and interim therapeutic restoration: a review of the literature. Dent J (Basel). 2019;7;7(1):E28.

26. da Mata C, McKenna G, Anweigi L, et al. An RCT of atraumatic restorative treatment for older adults: 5 year results. J Dent. 2019;83:95-99.

27. Balgi P, Katge F, Pradhan D, et al. Comparative evaluation of micro-leakage of two newer glass ionomer cements in primary molars immersed in three beverages: in vitro study. Ceylon Medical Journal. 2017;62(3):184-188.

28. de Medeiros Serpa EB, Clementino MA, Granville-Garcia AF, et al The effect of atraumatic restorative treatment on adhesive restorations for dental caries in deciduous molars. J Indian Soc Pedod Prev Dent. 2017;35:167-173.
29. Dornellas AP, Cavalcante KDT, Tedesco TK, et al. Molar decíduo infraocluido: Relato de um caso restaurado com cimento ionômero de vidro encapsulado, um ano de acompanhamento. Acta Biomedica Brasiliensia. 2018;9(2):124-129.

30. McNally ME, Matthews DC, Clovis JB, et al. The oral health of ageing baby boomers: a comparison of adults aged 45-64 and those 65 years and older. Gerodontology. 2014;31:123-135.

31. Raggio DP, Bonifácio CC, Bönecker M, et al. Effect of insertion method on knoop hardness of high viscous glass ionomer cements. Braz Dent J. 2010;21(5):439-445

32. Pereira J, Daroz LGD, Xible AA. Efeito da técnica de inserção na resistência mecânica de dois cimentos de ionômero de vidro de alta viscosidade. Rev Bras Pesq Saúde Vitória. 2018;20(1):79-84.

33. Davidson CL. Advances in glass-ionomer cements. J Appl Oral Sci. 2006;14:3-9.

34. Molina GF, Cabral RJ, Frencken JE. The ART approach: clinical aspects reviewed. J Appl Oral Sci. 2009;17(sp. issue):89-98.

35. Cho S, Cheng AC. A review of glass ionomer restorations in the primary dentition. Journal de l'Association dentaire canadienne. 1999;65(9):491495.

36. Taha NA, Ghanim A, Tavangar MS. Comparison of mechanical properties of resin composites with resin modified glass ionomers. J Dent Biomater. 2015;2(2):47-53

37. Avelino ELLC, Nogueira COP, Dorini AL, Caldas SGFR, Galvão MR Comparação da resistência à compressão entre o cimento de ionômero de vidro encapsulado e o sistema pó/líquido. RFO UPF. 2016;21(2):191-195.

38. Chammas MB, Valarini N, Maciel SM, et al. Resistência à compressão de cimentos de ionômero de vidro restauradores encapsulados. UNOPAR Cient Ciênc Biol Saúde. 2009;11(4):35-38.

39. Bonifácio CC1, Kleverlaan CJ, Raggio DP, et al, van Amerongen WE. Physical-mechanical properties of glass ionomer cements indicated for atraumatic restorative treatment. Aust Dent J. 2009;54(3):233-237. 